
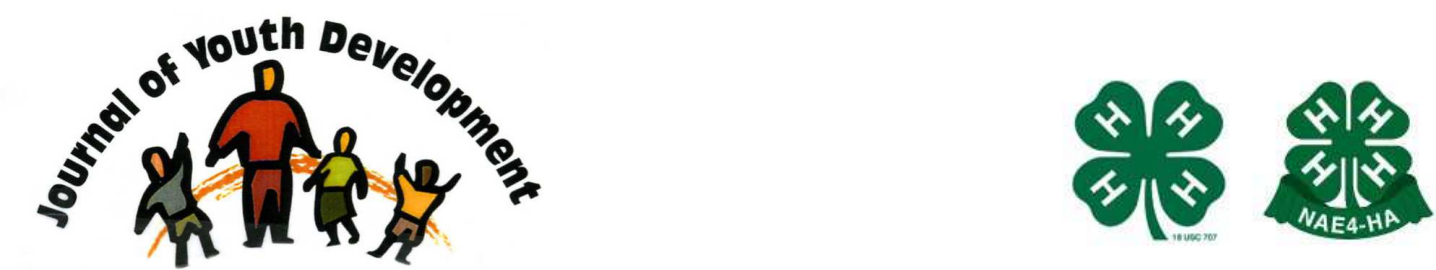

Bridging Research \& Practice

\title{
Engaging Youth Ages 8 to 12 as Volunteers: An Opportunity for Youth Development?
}

\author{
Charlene S. Shannon \\ University of New Brunswick \\ Fredericton, New Brunswick \\ Canada E3B 5A3 \\ cshannon@unb.ca
}

Brenda J. Robertson

Acadia University 


\title{
JOURNAL OF YOUTH DEVELOPMENT \\ bridging research and practice

\section{Engaging Youth Ages 8 to 12 as Volunteers: An Opportunity for Youth Development?}

\author{
Charlene S. Shannon \\ University of New Brunswick \\ Brenda J. Robertson \\ Acadia University
}

\begin{abstract}
Many youth programs are delivered to provide opportunities for youth to acquire the assets deemed essential to their development into caring, responsible adults. Engaging as a volunteer is considered an experience that provides access to the acquisition of key developmental assets. To date, research has focused on the positive outcomes that can result for adolescent volunteers with little attention being paid to volunteers younger than age 15 . This research explored whether and in what ways being a volunteer contributed to the development of youth ages 8 to 12. Interviews were conducted with 73 Boys and Girls Club youth and seven Club Executive Directors in Atlantic Canada. Results indicated that volunteering offered youth an opportunity to serve their communities, care for its members, and feel valued. Younger youth also developed various skills and experienced enhanced self-esteem and selfconfidence.
\end{abstract}

\section{Introduction}

Volunteers are critical to most communities in our society today. Many community organizations, causes, and events rely on individuals who provide service without monetary compensation. Volunteering is an activity or experience that not only contributes significantly to recipient organizations and the community (Edwards, Mooney, \& Heald, 2001; Quarter, Mook, \& Richmond, 2002), but also benefits the health and development (both personal and social) of the individual volunteer (Eccles, \& Barber, 1999; Febbraro, 2001; Shumer, 1994; Thoits, \& Hewitt, 2001; Youniss, McLellan, \& Yates, 1997). 
Researchers interested in child and human development have paid particular attention to the volunteer involvement of adolescents. Volunteering has been found to improve interpersonal skills and communication skills, increase knowledge, and develop organizational and managerial skills among 15-19 year olds (Febbraro, 2001). Adolescents who volunteer have better academic performance during high school and increased likelihood of pursuing post-secondary education (Eccles \& Barber, 1999). Experience with being a volunteer provides an opportunity for the reinforcement of positive social values and increases connection to community (Youniss, et al., 1997). Finally, volunteer service is an avenue toward adolescent civic development (Metz, McLellan, \& Youniss, 2003).

When examining statistics on volunteers in both Canada and the United States, however, individuals under the age of 15 have not been included (Hall, Lasby, Gumulka, \& Tryon, 2006; United States Department of Labor, 2007). Academic research on volunteers younger than 15 is also scarce. Therefore, little is known about the volunteer behaviors or experiences of youth younger than age 15 including how serving as a volunteer may contribute to their personal growth and development. The lack of attention to younger volunteers is unfortunate because many younger youth are having volunteer experiences. A variety of youth serving organizations such as Boys Scouts, Girl Guides and Scouts, 4-H Clubs, and Boys and Girls Clubs not only encourage younger youth to volunteer, but place community service as part of the organization's core values.

The first purpose of this study was to examine the volunteer experiences of youth ages 8 to 12 (middle childhood) from the perspectives of both youth who volunteer and leaders who facilitate those volunteer experiences. The second purpose was to explore whether and in what ways being a volunteer at this age can contribute to youth development.

\section{Literature Review}

The concept of youth development involves appreciating young people as assets or resources to be developed rather than as liabilities to be managed or controlled (Lerner, et al., 2005). Keeping with this philosophy of youth, asset-based models have been created which identify characteristics and behaviors necessary for young people to develop in order to become caring, responsible, and healthy adults.

The Search Institute (2003) developed a framework of 20 external and 20 internal developmental assets. The model identifies external assets as related to those positive experiences youth have in the communities through support they receive, actions that empower youth, the establishment of boundaries and expectations, and constructive use of time. The internal assets are related to the personal qualities that indicate positive growth and development in youth including making a commitment to learning, developing positive values, developing social competencies, and creating a positive identity.

A similar categorizing of desired outcomes for youth was developed by Lerner, Fisher, and Weinberg (2000) and has been termed the five Cs of positive youth development. The outcomes include:

- competence in academic, social, and vocational areas;

- confidence or a positive self-identity; 
- connections to community, family, and peers; character or positive values, integrity, and moral commitment; and

- caring and compassion.

Youth who exhibit these assets or indicators of positive youth development are considered to be thriving. Thriving has been conceptualized to seven outcomes:

- success in school,

- leadership,

- helping others,

- maintenance of physical health,

- delay of gratification,

- valuing diversity, and

- overcoming adversity (Scales, Benson, Leffert, \& Blyth, 2000).

There are many ways in which the assets of youth can be nurtured, and participation in youth programs is understood as a key opportunity to link youth with positive development (Roth, \& Brooks-Gunn, 2003a). This awareness has attracted the interest of youth workers and youth service organizations in developing programs and services that promote positive youth development. Roth and Brooks-Gunn (2003a) emphasize that it is not the specific focus of the activity (e.g., sports, cultural activities), but rather the opportunities provided through participation in the activities that is key. Program activities that are consistent with the youth development philosophy provide three sets of opportunities for youth: to build skills, to engage in real and challenging activities, and to broaden their horizons (Roth, \& Brooks-Gunn, 2003b). Community service was identified as one of the few specific activities within youth programs that afford all three opportunities (Roth, \& Brooks-Gunn, 2003a).

Based on Roth and Brooks-Gunn's research (2003a; 2003b; 2003c), engaging younger youth as volunteers may be a specific activity in which youth can access the opportunities they need to acquire the assets or achieve the outcomes associated with positive youth development. For example, among the external assets (Search Institute, 2003) are actions that empower youth. This includes youth feeling valued by their communities, being given useful roles in their communities, and providing service to their communities.

Examples of internal assets include placing high value on helping others, reporting having a high self-esteem, accepting and taking personal responsibility, and having empathy, sensitivity and friendship skills. These particular developmental assets are highlighted because many volunteer tasks promote behaviours such as helping others and providing service to communities. However, being a volunteer can also provide opportunities for youth to develop other assets through the outcomes associated with volunteering. Research on adolescents suggests that volunteering helps create a connection to community (Youniss, et al., 1997), promotes social and psychological development including building self-esteem (Kuperminc, Holditch, \& Allen, 2001), and encourages youth to be personally and socially responsible (Scales Blyth, Berkas, \& Kielsmeier, 2000; Sutherland, et al., 2006; Youniss, et al.).

Is it possible that younger youth who volunteer also have experiences that would help them work toward developing these particular assets? Volunteering is a medium through which the external benefits (positive experiences youth have in the communities) can be realized which in turn helps to facilitate achievement of the internal benefits (commitment to learning, developing 
positive values, developing social competencies, and creating a positive identity). Work by Robertson (1993) indicates that youth who engage in delinquent activities to fill their free time often make the decision to do so around age 8 years of age. As such, initiatives aimed at enhancing youth development as a means to fostering positive behaviors must occur much earlier than the teen years.

\section{Research Questions}

Three research questions were developed to explore the volunteer experiences of youth ages 8 to 12. They were:

1. What specific activities are youth ages 8 to 12 engaged in as volunteers? (What tasks are they performing? What roles are they taking on? For whom are volunteer tasks performed?)

2. What are younger youths' experiences with volunteering? (How do younger youth feel about the volunteer tasks they perform? What do they perceive are the outcomes of their participation as volunteers? How do leaders perceive the outcomes of the younger youths' volunteer experiences?)

3. Does younger youths' participation in volunteer activities contribute to asset development?

\section{Methodology}

\section{Study Participants}

The Boys and Girls Club of Canada was selected as the organization from which to recruit participants. The organization serves the needs of a wide range of youth (e.g., boys and girls from ages 6 to 18 and from various socio-economic statuses), operates in different types of communities (e.g., small rural, large urban), holds providing service to the community as one of its core values and incorporates volunteering as one of its program activities. The study involved 73 youth (31 males; 42 females) ages 8 to 12 and seven Executive Directors from Boys and Girls Clubs in Atlantic Canada.

\section{Recruitment and Data Collection}

After ethics approval was obtained from the universities of the co-investigators, Boys and Girls Clubs in each of the four Atlantic Provinces (Newfoundland, New Brunswick, Nova Scotia, and Prince Edward Island) were contacted about participating in the study. The goal in recruiting youth was to include 20 younger youth from each province - 10 from a rural Club and 10 from an urban Club. Initial contact was made with Club Executive Directors to determine which Clubs in each province had at least 10 youth between the ages of 8 to 12 who had volunteered in the previous two month.

In addition, the Executive Director of the Club needed to be willing to assist with organizing the data collection (e.g., to distribute the recruitment letters, collect parental consent forms, provide space for interviews to be conducted). One urban and one rural Club from each province were invited to participate. Choices were made based on those Clubs that fit the criteria and could participate within a four-month time frame. In Nova Scotia, only younger youth from one urban Club participated. Rural Clubs expressed interest, but none were able to participate in the data collection process within the specified time frame. 
Youth participated in semi-structured, face-to-face interviews that lasted between 20 and 45 minutes. Interviews took place at the Boys and Girls Club during times when the participants were attending programs. Each youth was asked the following questions:

- what the word volunteering meant to them,

- what experiences they had with volunteering,

- how they felt about those experiences,

- why they volunteered,

- what they liked and did not like about volunteering, and what challenges they faced in being volunteers.

Executive directors also participated in semi-structured, face-to-face interviews that lasted between 45 and 60 minutes. Discussion focused on their experiences with facilitating volunteer opportunities for the Club's youth, the effect that volunteering has had on participating youth, the challenges they face in creating and executing volunteer experiences for younger youth, and their impressions of how recipient organizations receive younger youth as volunteers.

\section{Data Analysis}

With the permission of youth and adult participants, each interview was audio-taped. Tapes were later transcribed verbatim. Data were analyzed using grounded theory procedures to establish themes within the data (Strauss, \& Corbin, 1990). The transcripts were systematically reviewed and coded in stages. The first stage involved open coding where categories of concepts were developed and given labels. For example, descriptions of volunteer experiences that involved youth helping people in the community were labeled "community service." In the second stage, connections between categories and between categories and subcategories were explored. This involved examining the relationship between youths' experiences with "community service" and outcomes of volunteering such as "skill development" or "selfconfidence."

Once connections between categories or concepts were established, each transcript was reviewed again to determine whether the data fit with established connections and whether the themes were inclusive of data across all interviews. Throughout the analysis a constant comparison method (Glaser, \& Strauss, 1967) was also used whereby the responses of youth participants and those of the Executive Directors were compared and contrasted to lend credibility to the connections made between categories and to the themes that were developed.

\section{Results}

Two main themes were evident throughout the data collected from both younger youth and Executive Directors. Volunteering was an opportunity to connect with community and to experience personal development. The manner in which these themes were linked to youth development is discussed.

\section{Connecting with Community: Providing Service}

The Executive Directors viewed volunteering as a way to facilitate youths' healthy and active engagement with communities. The goal was to foster a sense of pride in community along with a sense of responsibility to participate in community. One Executive Director described a new program that his Club was instituting: 
The program is about kids from the Boys and Girls Club helping out other organizations - helping out the $Y$, helping out seniors. We really want to get them out in the community so they know there is more than just the Boys and Girls Club and themselves.

Through the efforts of Club staff, the youth participated in an array of activities that they perceived as volunteering. In many cases, youth identified participating in more than one volunteer task in the previous few months. Thirty youth had been involved in clean up days where they spent time picking up garbage. Twenty-seven youth discussed ways in which they volunteered around their Club (e.g., helping staff set up an activity, doing dishes after lunch). Several $(n=17)$ youth were engaged in volunteer tasks that saw them take on leadership roles such as being "counselors in training" or providing leadership to activities or events being organized for younger Club members. Some youth $(n=11)$ interacted with community members by visiting seniors, helping out at the food bank, or serving meals at a special event.

The largest number of youth $(n=39)$, however, had participated in fundraising. Fundraising activities ranged from getting pledges for activities such as a walk-a-thon to raise money for their Club to organizing car washes to raise money for a charity or cause such as the March of Dimes, Children's Wish Foundation, or the Diabetes Association.

Most of the youth provided service to their communities through the volunteer tasks they performed. It is important to note, however, that there were also cases in which the recipients of the youths' volunteer efforts were the youth themselves (e.g., raising money so the Club could get new equipment). All the Executive Directors spoke about the need to "hook" younger youth as volunteers. One strategy for doing that was to start them off with volunteer tasks that produced tangible benefits for the youth.

Some of our biggest challenges remain the incentives that are available to children. As much as it may sound great to us as service providers to 'volunteer,' kids often want to know what they will get out of it. Once they are engaged it is much easier to maintain them because the benefits of volunteering become more evident to them.

This challenge that Executive Directors faced illustrates that when younger youth serve as volunteers, they are not necessarily serving their communities. Youth this age do, however, have the capacity to perform tasks that help to serve the community. Executive Directors believed that youth could engage in a wide range of volunteer tasks: "They have tons of energy. I think kids aged 8 to 12, with supervision, can definitely organize something, plan, and be creative." The younger youth also identified a wide range of tasks that they felt they could perform if asked including yard work, painting, carrying groceries, selling items, and teaching others how to do things.

\section{Connecting with Community: Caring}

There was an emotional component that the youth associated with performing the volunteer tasks. Many expressed having a sense of sympathy or empathy toward others. These younger youth cared about their communities and its members. In particular, they expressed concern for various vulnerable populations such as seniors, individuals with disabilities, people who were ill, and those who are "less fortunate." Twenty-eight percent of the younger youth cited one of the reasons they volunteered was to help people. They described the pleasure they received from 
helping other people in their community. For example, one 10-year old girl said, "I have learned that helping out in the community makes you feel good."

Some Executive Directors emphasized that explaining to youth the reasons why they were participating in a particular fundraiser (e.g., for the Food Bank) helped the youth develop knowledge about the population they were volunteering to help (e.g., those living in poverty).

We explain what the Make a Wish Foundation is so the youth understand that there are other kids their age with serious illness and that their fundraising will help them with their wish being granted. We talk about how that gives the kids hope - something to look forward to and a little break from thinking about their illness. I think when you do that, it helps the youth to understand what they are doing and really get into it.

Many youth discussed the ways in which their participation as volunteers affected their community and some of the people in it. For example, when a 12-year old girl was asked why she volunteered for a community clean up, she responded, "For the town because it makes our town a lot nicer when tourists come. They don't have to look at a town full of garbage." A 12year old male articulated quite well why he liked spending time with seniors at the local care home, "Because it was giving them something inside; telling them that people do care about them." As a final example, one 11-year old girl said she raised money for Make a Wish Foundation, "so kids that are sick know that other kids care about them."

Interestingly, several $(n=23)$ of these younger youth seemed to understand that volunteering was something that caring people do. When youth were asked why they thought not everyone volunteers their time, the youth made links to lack of caring.

They like their friends more than helping other people. They don't really care about younger children. They probably only care about themselves and nobody else, and they just care about them having fun and not other people probably. (Female, 11 years old)

I think that volunteering is a good way to show somebody that you care. (Female, 11 years old)

They probably don't [volunteer] because they don't really care about people who are sick or less fortunate. Like, when you volunteer, you show that you care. (Male, 10 years old)

Some of the volunteer experiences created opportunities for youth to learn about various nonprofit organizations and what those organizations do to care for the community and specific members within it..

\section{Connecting with Community: Feeling Appreciated and Valued}

Engaging as volunteers helped youth to feel they are valued members of their community. Showing support and appreciation youth is important to younger youth feeling valued. In some cases, recipient organizations (e.g., Diabetes Association) or event organizers (e.g., community clean up) provided a tangible reward to show appreciation. In other cases, the positive 
responses younger youth received from recipients of their volunteer efforts, helped them to feel their roles were important.

After the clean up, we got an ice cream. It was a thank you because of our hard work. (Male, 9 years old)

We did the talent show and the old people were smiling and clapped for us. You know you are making them happy. They say, "Come back again." They are always happy when we go. (Male, 10 years old)

When I see the kids having fun [at the Family Fun Day], I feel good about running the games. And some parents thanked me because their kids had fun and you feel important. (Female, 12 years old)

Interestingly, when support and appreciation for younger youths' volunteer efforts was absent, some of the youth expressed dissatisfaction with the volunteer experience.

Sometimes people forget to say thank you. That is what I dislike about volunteering because... it just says... because if you don't say thank you, it is really just saying that you don't appreciate the hard work their putting in to helping you (Male, 12 years old)

Some people were really rude to me when I was trying to sell tickets. We were trying to raise money for a good cause [Make a Wish Foundation] and they were probably being rude because we were kids.

Interviewer: Will you do it again... sell tickets for the draw?

I don't know. (Female, 11 years old)

These quotations demonstrate there is a potential risk that youth may leave their volunteer experience feeling unappreciated or undervalued.

\section{Personal Development}

Both youth and Executive Directors identified ways in which participating as volunteers contributed to youths' personal growth and development. When asked what they learned, many youth explained realizing they were capable of doing things they did not think they could do (e.g., approach people for money when fundraising; providing leadership to activities or games). A few youth talked about getting over or managing their shyness and improving their social skills.

I didn't know that just playing games with the elderly at the nursing home... that I could make them feel happy. I didn't know I could do that (Male, 9 years old).

I learned when I volunteered that I do have enough courage to get up and speak to people about a good cause and I do have enough courage to talk to strangers when I have to if it's something important. I learned stuff I never thought I could do. I never would think I could go up and ask people if they have any spare change because I don't even like calling family for something, so I never knew I could do that until I started volunteering. (Female, 11 years old)

I find that since I started volunteering, I get more respect. Like, respect from the younger kids and from adults. That makes me feel good, you know, that I'm finally doing something that I'm respected for. (Male, 11 years old) 
The positive effects that being a volunteer can have on youth was a key factor motivating Executive Directors to facilitate volunteer opportunities. Executive Directors indicated that various volunteer tasks will facilitate the development of different skills. For example, preparing and putting on a talent show for seniors is an opportunity for youth to develop planning, organizing, and decision-making skills. Selling tickets as part of a fundraiser will be an opportunity for youth to work on their communication skills.

[Counselors-in-training] are volunteering their whole day, their whole summer and in return, they learn leadership skills and they have a lot of fun with it. They take on a lot of responsibility as well.

Sometimes I take a volunteer to help in the main office. They have to give up the activities going on at the Club that day, but they learn to answer the phone properly and take messages, and how to file. It's fun for them because there is status and prestige that goes with that task, but they are also learning some practical skills.

The Executive Directors were also aware that the personal characteristics of each younger youth influenced the developmental outcomes they experienced from being a volunteer.

For some of the kids here that you interviewed, they don't experience much success at school or don't have the most encouraging home environments so for them to go out and volunteer is so important because they learn they can be successful at things. For those kids developing self-confidence and self-esteem from having success is more important than any specific skill they may learn.

We have a lot of kids here who are shy, don't communicate a lot and you get them in an atmosphere where they are volunteering with a group of people and their social skills are going to improve along with their communication skills, their confidence, their self-worth, self-esteem. They are going to start feeling good about themselves. And once you start feeling good about yourself, the sky's the limit.

There is evidence that younger youth can experience personal development through volunteering. In some cases, development took the form of acquiring specific skills while in others the focus was on the youth learning something about themselves that opened their eyes to their personal capacities.

\section{Conclusions and Discussion}

Youth ages 8 to 12 need constructive ways to spend the discretionary time that is available to them (Search Institute, 2003). Volunteering is one activity which enables younger youth to develop some of assets that will contribute to their becoming caring and responsible adults. Youth this age have the ability to participate in and perform a wide range of volunteer tasks that can foster the development of communication, planning, leadership, social, and decisionmaking skills. These are skills that contribute to positive youth development (Roth, \& BrooksGunn, 2003c). 
Among the volunteer activities in which younger youth can engage, participating in community initiatives may be particularly critical. First, such initiatives provide opportunities for adults to see that youth this age are capable of helping out in their community and may help shift attitudes about youth away from the deficit model (i.e., seeing youth as liabilities) and toward viewing them in terms of the abilities they do have and the potential they hold. Youth also have the chance to broaden their horizons (Brooks, \& Gunn, 2003a) through exposure to different members of their community with whom they may not have previously had interactions or developing an awareness of situations that various individuals in the community face

For these outcomes to occur, however, organizations who utilize volunteers along with leaders working with youth need to:

- $\quad$ First recognize that youth this age do have the ability to contribute.

- Next, suitable volunteer opportunities for younger youth need to be created or provided - opportunities that are age appropriate, facilitate the development of various skills, and when possible, involve helping others so that youth can develop empathy and positive attitudes towards others (Johnson, Beebe, Mortimer, \& Snyder, 1998).

- Finally, appreciation for the efforts that younger youth put forth needs to be shown.

Certainly, it is difficult to manage how the general public will respond to youth who are volunteering their time. Therefore, the interactions between recipient organizations and the younger youth who volunteer are critical. Acknowledgement and appreciation not only help youth to feel what they do matters, but also encourages their continued involvement as volunteers and the continued opportunity to reap the various other benefits associated with volunteering.

Engaging youth as volunteers earlier in their lives may enable the development of a number of key assets prior to the onset of adolescence. Entering adolescence with a sense of connection to community, self-confidence, and an interest in and desire to help others may assist youth in more positively adapting and/or responding to the changes and challenges that are inherent during that stage of life (Olsson, Bond, Burns, Vella-Brodrick, \& Sawyer, 2003).

There is a concern about the declining number of volunteers and the awareness of that participating as a volunteering during youth predicts service involvement in later life (Metz, et al., 2003). Therefore, securing the interest of younger youth in volunteering and helping them to experience the positive, intrinsic rewards that are associated with giving one's time may lead to a life-long interest in volunteering. Younger youth are available resources that may have been overlooked and underutilized by organizations needing volunteers.

With the awareness of what young volunteers can do and the positive outcomes they can experience, future research may need to focus on understanding how to motivate younger youth to become involved as volunteers and how to maintain that involvement so as to allow access to the benefits associated with long-term volunteer engagement. Consideration may also need to be given to determining which volunteer experiences (e.g., food drive, canvassing for a non-profit organization) and tasks within those experiences provide the best opportunities for the development of the widest range of assets. 


\section{References}

Eccles, J.S., \& Barber, B.L. (1999). Student council, volunteering, basketball, or marching band: What kind of extracurricular involvement matters? Journal of Adolescent Research, 14, 10-43.

Edwards, B., Mooney, L., \& Heald, C. (2001). Who is being served? The impact of student volunteering on local community organizations. Nonprofit \& Voluntary Sector Quarterly, 30, 444-461.

Febbraro, A. (2001). Encouraging volunteering among Ontario youth. Retrieved January 31, 2007 from http://www.givingandvolunteering.ca/reports/1997 ontario youth/page02.asp

Glaser, B.G., \& Strauss, A.L. (1967). The discovery of grounded theory. Chicago: Aldine.

Hall, M., Lasby, D., Gumulka, G., \& Tryon, C. (2006). Caring Canadians, involved Canadians: Highlights from the 2004 National Survey of Giving, Volunteering and Participating (Catalogue No. 71-542-XIE). Ottawa, ON: Statistics Canada.

Johnson, M.K., Beebe, T., Mortimer, J. T., \& Snyder, M. (1998). Volunteerism in adolescence: A process perspective. Journal of Research in Adolescence, 8, 309-332.

Kuperminc, G.P., Holditch, P.T., \& Allen, J.P. (2001). Volunteering and community service in adolescence. Adolescent Medicine: State of Art Reviews, 12, 445-457.

Lerner, R.M., Fisher, C.B., \& Weinberg, R.A. (2000). Toward a science for and of the people: Promoting the civil society through the application of developmental science. Child Development, 71, 11-20.

Lerner, R.M., Lerner, J.V., Almerigi, J.B., Theokas, C., Phelps, E., Gestsdottir, S., et al. (2005). Positive youth development, participation in community youth development programs, and community contributions of fifth-grade adolescents: Findings from the first wave of the 4-H study of positive youth development. The Journal of Early Adolescence, 25, 17-71.

Metz, E., McLellan, J., \& Youniss, J. (2003). Types of voluntary service and adolescents' civic development. Journal of Adolescent Research, 18, 188-203.

Olsson, C.A., Bond, L., Burns, J.M., Vella-Brodrick, D.A., \& Sawyer, S.M. (2003). Adolescent resilience: A concept analysis. Journal of Adolescence, 26, 1-11.

Quarter, J., Mook, L., \& Richmond, B.J. (2002). What volunteers contribute: Calculating and communicating value added. Toronto: Canadian Centre for Philanthropy.

Robertson, B.J. (1993). An investigation of leisure in the lives of adolescents who engage in delinquent behavior for fun, thrills, and excitement. Unpublished doctoral dissertation. Eugene, OR: University of Oregon.

Roth, J.L., \& Brooks-Gunn, J. (2003a). What exactly is a youth development program? Answers from research and practice. Applied Developmental Science, 7, 94-111. 
Roth, J.L., \& Brooks-Gunn, J. (2003b). What is a youth development program? Identifying defining principles. In R.M. Lerner, F. Jacobs, \& D. Wertlieb (Eds.), Promoting positive child, adolescent, and family development: $A$ handbook of program and policy innovations (Vol. 2). Thousand Oaks, CA: Sage.

Roth, J.L., \& Brooks-Gunn, J. (2003c). Youth development programs: Risk, prevention and policy. Journal of Adolescent Health, 32, 170-182.

Scales, P., Benson, P., Leffert, N., \& Blyth, D. (2000). Contribution of developmental assets to the prediction of thriving among adolescents. Applied Developmental Science, 4, 27-46.

Scales, P., Blyth, D., Berkas, T., \& Kielsmeier, J. (2000). The effects of service-learning on middle school students' social responsibility and academic success. Journal of Early Adolescence, 20(3), 332-358.

Search Institute. (2003). 40 developmental assets. Retrieved February 4, 2007, from http://www.search-institute.org/assets/40AssetsMC.pdf

Shumer, R. (1994). Community based learning: Humanizing education. Journal of Adolescence, $17,357-367$.

Strauss, A., \& Corbin, J. (1990). Grounded theory methodology - An overview. In N.K. Denzin and Y.S. Lincoln (Eds.), Handbook of Qualitative Research (pp. 273-285), Thousand Oaks, CA: Sage Publications.

Sutherland, D., Doerkson, M., Hanslip, T., Roberts, J., Stewart, S., Sagnes, E., \& Friesen-Storz, T. (2006). Youth volunteerism: Measuring the benefits of community service learning programs. Toronto, ON: Imagine Canada, Knowledge Development Centre

Thoits, P.A., \& Hewitt, L.N. (2001). Volunteer work and well-being. Journal of Health and Social Behavior, 42, 115-131.

United States Department of Labor. (2007). Volunteering in the United States, 2006. Retrieved January 31, 2007, from http://www.bls.gov/news.release/pdf/volun.pd

Youniss, J., McLellan, J., \& Yates, M. (1997). Community service and social responsibility in youth. Chicago: University of Chicago Press.

(C) Copyright of Journal of Youth Development Bridging Research and Practice. Content may not be copied or emailed to multiple sites or posted to a listserv without copyright holder's express written permission. Contact Editor at: patricia.dawson@oregonstate.edu for details. However, users may print, download or email articles for individual use.

ISSN 2325-4009 (Print); ISSN 2325-4017 (Online) 